\title{
Scaffolding to Promote Critical Thinking and Learner Autonomy Among Pre-Service Education Students
}

\author{
Dr. Sara Weinstein (Corresponding Author) \\ Efrata Teachers College \\ Dept: Bible and Rabbinics, Ben Jephuneh 17, Jerusalem, Israel \\ Tel: 972-546242107_E-mail:sara13727@gmail.com
}

\begin{abstract}
Dr. Devorah Preiss
Dept: Educational technology, Efrata Teachers College, Ben Yefuneh 17, Jerusalem, Israel Tel: 972-526139946_E-mail: devorahpreiss@gmail.com
\end{abstract}

Received: August 21, 2016

doi:10.5296/jet.v4i1.9871
Accepted: January 4, $2017 \quad$ Published: February 28, 2017

URL: http://dx.doi.org/10.5296/jet.v4i1.9871

\begin{abstract}
This study explored the use of a scaffolding technique in order to develop critical thinking skills and dispositions while using the infusion method of teaching critical thinking within the context of specific subject matter. Two specific skills were examined: the students were asked to compare and contrast Biblical textual stories (analysis) and then to generate abstract categories to describe the elements they had compared (evaluation). The disposition examined was the self confidence to reason independently, without teacher direction, in order to encourage learner autonomy. The study developed as action research in a teachers college Bible class, after pre-service education students complained that they were unable to compare and contrast texts on their own. In an attempt to solve this problem, the study began with a preliminary non-textual exercise involving analyzing and evaluating two everyday leisure activities. It then continued by transferring these skills to Biblical text comparisons. Findings showed that beginning the study with the scaffolding step of a non-textual exercise before moving on to text comparisons was an effective method of helping students overcome their former reluctance to autonomously compare texts without teacher intervention.
\end{abstract}

Keywords: action research, critical thinking skills, critical thinking dispositions, infusion method, learner autonomy, scaffolding

\section{Introduction}

Developing the ability to think critically is a highly valued goal amongst modern educators and policymakers (Abrami et al., 2015). The ability to analyze and evaluate arguments, to recognize personal preconceptions or prejudices, to support conclusions, to solve problems, 
and to come to 'intelligent decisions about what to believe and what to do' (Basham et al., 2011, 1, 27) are all skills which are dependent on the ability to think critically. Teaching thinking is driven by the desire for a kind of education that will provide students with the skills and dispositions that they need to face new challenges in the future (Wegerif, Li, \& Kaufman, 2015), be they academic, personal or moral (Norris, 1985; Paul \& Elder, 2009; Samanci, 2015).

Despite the importance of teaching these skills, research has shown that many high school students in the United States are most comfortable with 'lower order thinking' involving the passive absorption of information which is then repeated back on tests (Basham et al., 2011, 1). As a result, students have difficulty solving problems that involve abstract thinking (Nickerson, Perkins, \& Smith, 2014). As the emphasis in college switches from learning 'what to think' to learning 'how to think' in order to foster independent learning and thinking (Basham et al., 2011, 1), college freshmen need to be taught such higher order thinking skills (Giuliano \& Sullivan, 2007, Nickerson, Perkins, \& Smith, 2014).

Educators, researchers and policy makers are involved in a continuing struggle to successfully teach critical thinking (CT) on all levels, as reflected in Abrami et al.'s comprehensive review article (2015). In higher education, vast resources and extensive scholarship have been devoted to the study of CT pedagogy and assessment (Behar-Horenstein \& Niu, 2011; Florence, 2014). Recent research focusing specifically on pre-service education students has examined diverse issues such as the impact of CT skills on moral judgement competence (Samanci 2015), on problem solving abilities (Ocak \& Eray, 2016), and on using interactive digital tools to improve CT (Sendag, Erol, Sezgin, \& Duldakir, 2015).

\subsection{Infusion approach to promoting $C T$}

While CT skills are often taught in a generic fashion as classes devoted to the teaching of thinking skills alone - independent of any specific subject area - an alternative and possibly more effective method is to teach these skills within the context of specific subject areas, in what has been termed the infusion method (Behar-Horenstein \& Niu, 2011; Abrami et al., 2015). In this method, while subject matter is taught, the CT skills being developed are simultaneously made explicit, as studies have shown that CT skills are more likely to improve when students are made aware that acquiring these skills is a distinct educational goal (Florence, 2014).

This infusion method has been implemented within the context of many academic areas, such as science (Silva, Lopez, \& Silva, 2013; Hugerat \& Kortam, 2014), nursing (Maskey, 2008), math (Rodrigues, 2012), Jewish studies (Raviv, 2011; Raviv \& Kaniel, 2013) and English language (Corona \& Gonzales-Quiceno, 2008, Ministry of Education, State of Israel, 2013).

\subsection{Scaffolding to promote $C T$}

A strategy commonly used to develop CT skills within the context of the infusion method is the use of scaffolding. In an educational setting, scaffolding refers to a temporary and supportive structure provided by the teacher to help students accomplish a task that they otherwise would not have been able to accomplish at all, or as readily. Scaffolding can also 
assist students on an emotional level, by reducing frustration (O'Connor, McDonald and Ruggiero, 2014) and enabling them to become independent learners with less stress (Murray \& McPherson, 2006).

According to Pol, Volman and Beishulizen (2010), scaffolding consists of three components: contingency, fading and transfer of responsibility. 'Contingency' necessitates that the teacher determine the students' current level of competence and then tailor the support to the students' needs. 'Fading' involves the gradual withdrawal of teacher support, leading to the third characteristic - the 'transfer' of responsibility for the performance of the task from teacher to student - leading eventually to the student taking more control over his learning.

Studies demonstrating the effectiveness of scaffolding in CT education have been conducted in many different academic disciplines such as science (Valanides \& Angeli, 2005), math (Bakker, Smit, \& Wegerif, 2015), history (Graves \& Avery, 1997), and reading (Fitzgerald \& Graves, 2004; Many \& Aoulou, 2014). This study applies the infusion method discussed above and a scaffolding strategy to the teaching of CT skills to pre-service education students in a small religious women's teachers college in Jerusalem. The study took place in the context of a required Bible course given during the freshman year of the B.Ed. program. CT skills were thus taught in a content-specific manner, as they were made explicit within the context of thoughtful and comprehensive subject matter instruction (Abrami et al., 2015).

For teachers in training, acquiring CT skills and dispositions is of two-fold importance. In addition to CT being an essential component of their own development as effective teachers themselves, (Torff, 2005; Hadar \& Brody, 2010, 2012), teachers in training will also ultimately be responsible for passing on CT skills and dispositions to the next generation, their students.

\section{Goals of Study}

Research has shown that two separate steps are essential to the development of critical thinking: the first involves teaching the cognitive skills themselves, and the second involves developing the learners' disposition to use those skills (Tishman, Perkins, \& Jay, 1995; Facione 1990 in Abrami et al., 2015). Merely teaching students the skills to think critically is not enough. To effectively use those skills, one must develop thinking dispositions, defined as 'inclinations or habits of mind that benefit productive thinking', and 'ongoing, abiding tendencies in thinking behavior exhibited over time across diverse thinking situations' (Tishman, Perkins, \& Jay, 1995, 37).

This study explores a focused attempt to develop a teaching strategy aimed at improving education student's academic performance by developing both CT skills and a CT disposition. Two specific CT skills were addressed in this study. The first was the ability to compare and contrast texts. The second was the ability to formulate abstract criteria to describe what they had compared. Within the framework of Blooms' revised taxonomy, they were engaging in the fourth and fifth categories of knowledge - analyzing textual material and then evaluating their findings (Krathwohl, 2002). 
The CT disposition addressed in this study was the ability to accomplish these skills independently, without teacher direction, thus developing the students' ability to learn independently. Ultimately, the goal was to boost their self confidence in their ability to reason, one of the nineteen critical thinking dispositions listed by the American Philosophical Association's report on critical thinking (Facione, 1990, Abrami et al., 2015).

In order to 'make thinking visible' and thereby more effectively achieve the goal of furthering their CT skills and disposition (Ritchart, Church, \& Morrison, 2011, 29), the students were told that the purpose of the experiment was to help them learn how to compare and contrast Biblical stories so that they could reach a deeper understanding of these stories and gain new insights into each story. This goal was also stated in writing in the worksheet containing the charts they filled out in class. Richart, Church and Morrison refer to the need for teachers to uncover how their students think about their own thinking as 'unpacking thinking' (ibid 3, 15-17). In this exercise, however, this term is used in a somewhat modified way. The thinking skills introduced in the exercise were 'unpacked' for the students - by the instructor - by dividing the exercise into stages, each stage demanding more advanced thinking skills which were explained and discussed.

\subsection{Close reading of texts as a tool for critical thinking}

Close reading of texts is an essential tool in developing critical thinking. Through the process of textual analysis, students actively engage with the text, learn to identify its purpose and clarify the important ideas being conveyed. Active engagement in textual study facilitates questioning, summarizing, and connecting ideas from one text to another (Elder and Paul 2004; Paul and Elder 2012). Given the tendency of students to 'think of the material that they are learning as disconnected sentences from a textbook or lecture' (Elder and Paul 2008), an important educational goal is to enable them to find connections between the ideas they are learning both within and across different disciplines (ibid). In order to facilitate this active type of learning, the students in this study were engaged in a search for similarities and differences between Biblical texts, leading to a discussion of core ideas and insights that they discovered.

The lesson began with an exercise taken from the students' everyday life experience, involving comparing and contrasting two different leisure activities and developing abstract terms to describe what they had compared. The students were thereby provided with intrinsic support for learning CT, since they were encouraged to use thinking dispositions in a context that interested them (i.e. leisure activity) and provided them with 'pleasurable cognitive engagement' (Tishman, 2001, 74; Abrami et al., 2015). This methodology, also referred to as 'authentic or anchored instruction' (Abrami et al., 2015), was utilized by Saiz and Rivas to develop an intervention program aimed at teaching thinking skills more effectively. In order to establish interest and motivation in the thinking process, they presented their students with dilemas and choices to be made regarding daily life activities such as education, health and leisure (2011).

While studies have shown that such authentic or anchored instruction is a particularly effective technique for teaching CT skills (Abrami et al., 2015), it should be noted that the 
'authentic' everyday life activity in this study was not the core of the lesson. Instead, as described above, it was used as a tool to model and explain 'the language of thinking' (Tishman, Perkins and Jay 1995, 21, 31-32). This tool was thus used as a scaffold to aid in the transfer of their new CT skills and disposition to the content-specific field of text study (Dewitz \& Graves, 2014).

\subsection{Learner-centered learning}

Developing the ability to compare and contrast different stories and other texts can be accomplished via at least two different teaching models; the first being teacher-centered, and the second, learner-centered (Kathy, 2003). In the teacher centered model, students might be asked to compare two stories by using criteria provided by the teacher, such as comparing the hero in each story. Teachers can have good reasons for providing criteria for comparison. They may have specific ideas that they want to teach yet still want the students to be involved in the learning process and therefore enable the students to 'discover' at least part of the lesson independently. The class can then discuss the meaning of their findings, with increased student participation as a result of the teacher's assignment.

While providing students with criteria for comparison is thus a useful and sometimes necessary technique in textual study, a learner-centered thinking skills oriented teaching goal would be empowering students to discover their own criteria for comparison, beyond and/or instead of those proposed by the teacher. Instead of asking the students to look for what the teacher wants them to find, the teacher can relinquish control over the content of the discourse in the classroom and enable the student to look for what is important to her (Jacome, 2012; Tillapaugh \& Haber-Curran, 2013). In the learner-centered model, the the role of the teacher shifts from being the deliverer of information to 'fostering students' engagement with ideas' (Ritchart, Church, \& Morrison, 2011, p. 26) by encouraging the learner to think about texts in an autonomous and creative manner. This learner-centered model was the model utilized in this study.

\subsection{Learner autonomy}

Following Benson's widely used definition of learner autonomy as the ability to 'take control over one's own learning' (2013, p. 2), this study aimed at encouraging the students' autonomy in learning, as reflected in both their 'ability and willingness to make choices independently' as part of their learning process. (Littlewood, 1996). The students were provided with a tool to help them analyze texts independently, with the hoped for result of reducing their reliance on the 'all-knowing' teacher. The goal was thus to build their critical thinking disposition in order to empower them by boosting their self- confidence in 'their own ability to reason' (Abrami et al., 2015) and to function as independent learners (Jacome, 2012).

\section{Context of Study}

This study developed as the result of difficulty expressed by students when asked to compare and contrast Biblical stories. The students repeatedly requested that the teacher help them compare texts, stating that they did not know what to compare, and could not think on their own of criteria for comparison. 'We don't know what to look for' or 'tell us what to look for' 
were oft-heard complaints/requests. The difficulty experienced by these college freshmen in Israel in comparing texts and then abstracting criteria to describe their text comparisons thus corresponds to the research discussed above regarding students in the United States who need to be taught CT skills when they get to college.

While this seems to be a problem faced by many college students, the difficulty experienced by the specific group of students in this study, however, may have been caused by or intensified by two factors unique to their prior education. The first factor involves the nature of their prior religious education. Most of the students had attended religious elementary and high schools before attending the college. The goal of their religious education had been to promote and strengthen Orthodox Jewish belief and practice. Teaching methods in many religious schools in Israel can be described as exclusivist, presenting only the 'correct' point of view without promoting discussion or consideration of varying points of view. Alternatively, they can be described as inclusivist, presenting varying points of view in order to inoculate the children against the opposing points of view (Jawoniyi, 2015). Either way, reliance on religious authority as the correct source of understanding religious texts is highly encouraged (Lehmann, 2008; Tau, 2002, 13-14; Bazak, 2013, 351-352).

As a result of these prior educational experiences, habits of independent, critical thinking had not been encouraged (Perkins, 2001, 160; Basham et al., 2011, 15-16). A parallel to this phenomenon in Orthodox Jewish schools can be found in Christian institutions, as CT education has been resisted due to fear that it could lead to criticism of the Scriptures, religious questioning and eventually, rebellion against the Church (Florence, 2014).

While reluctance to $\mathrm{CT}$ education can thus be religiously based, it can also be culturally based, as certain cultures can present obstacles to developing student autonomy. In Asian countries that have a Confucian heritage culture, submission to power and authority is expected (Lo, 2010). In China, for example, there is great concern for the teachers not losing 'face', i..e student respect, resulting in student reluctance to differ with the teacher (Ho \& Crokall, 1995). Similarly, Hong Kong students have been characterized as passive, dependent and shy (Pierson, 1996, 52; Chan, 2001). They consequently typically see knowledge as something transmitted by the teacher, who is in full control of their learning, rather than something which they are able to discover on their own (Chan, 2001). More recent studies have shown that teachers who wish to change this situation by implementing new teaching approaches which relinquish power to their students face greater difficulty than do their Western counterparts (Lo, 2010).

The authority based nature of prior religious or cultural education can thus contribute to a lack of exposure to CT, effecting both girls and boys. A second factor, however, is gender based. In the field of Jewish studies, one particularly useful discipline in teaching thinking skills as well as autonomous learning skills is Talmud study, a main subject of study in religious boys schools in Israel. Talmud study involves a multitude of higher order thinking skills, amongst them logical analysis, text comparison, formulation of questions and deep understanding of conflicting perspectives, and the use of modern CT thinking skills activities as a pedagogic tool to enhance Talmud study is an area of current research (Raviv \& Kaniel, 
2013). According to the current Israeli Ministry of Religious Education curriculum, one of the explicitly stated goals of teaching Talmud is the acquisition of skills that will prepare the student for independent learning' (Ministry of Education, State of Israel, 1987, 2.3:7).

These benefits, however, are experienced mainly by boys in the religious education in Israel. For in most Israeli religious schools, Talmud is not taught to girls as it is considered by many Rabbinic authorities to be a subject necessary to boys education but not at all necessary for girls (Aviner, 1994; Ariel, 2012). On the high school level, Talmud is, thus, not a required subject for girls (Ministry of Education, State of Israel, 1987, 11:14), and in the minority of high schools in which Talmud is actually offered as an option to girls, they are generally tested on less material on the matriculation exams than are boys (ibid).

The female participants in this study, as a result, began college with a lack of exposure to critical thinking for two reasons which apply specifically to their population group. The first, which would apply to the men in this population group as well, is their prior authoritarian based religous education which often actually discourages critical thinking. The second, unique to girls educated in this system, is their lack of exposure to Talmud study.

\section{Methodology}

A class of twenty four women students ages 20-24 participated in this study. All were native Israelis, studying toward a B.Ed. degree in either early childhood education, special education, or elementary school education. A series of scaffolded classroom assignments were developed by this author as an application of action research methodology learned in a professional development workshop for teacher-educators designed to infuse higher order thinking skills in college courses (Hadar \& Brody, 2010, 2012). The students were told that they were participating in the instructor's experimental study of teaching methodology, that their answers would remain anonymous and would not be graded.

\subsection{Action research}

The chosen methodology for this study was action research, as it was directed toward solving 'an immediate problem of practice' and aimed, ideally, toward more effective teaching in the future (Hine, 2013). The four necessary steps for action research as defined by Kemmis and McTaggart were followed here, as an intentional and systematic inquiry into teaching practice was devised utilizing planning, acting, observing and reflecting (2005).

The study also utilized the two stages of action research as defined by Blum, namely, the diagnostic stage and the therapeutic stage (Cohen, Manion, \& Morrison, 2005). In the diagnostic stage, a problem was identified and analyzed, and an ensuant hypothesis was developed. The identified problem was the difficulty experienced by the students when asked to compare and contrast texts on an independent basis.

The ensuant hypothesis was that this difficulty was the result of not having been asked to accomplish tasks like this in their prior years of education. The problem was thus seen as lack of prior skill building in their education, rather than an innate cognitive limitation. The students were simply used to having the teachers tell them what elements to compare and contrast. 
This hypothesis was then tested in Blum's second stage: the 'therapeutic' stage of the study. This study examined how a scaffolding exercise beginning with the familiar would help students improve their skills in the unfamiliar - namely, Biblical text comparison. The following scaffolding strategy was developed in order facilitate independent textual analysis and evaluation and address the students' difficulty.

\subsection{The seven scaffolding steps}

As mentioned above, in order to motivate the students to engage in CT, the first step in the scaffolding strategy was an exercise taken from their everyday life. In order to establish a 'safe' environment', the activity chosen was pleasant and easy to discuss; the students were asked to compare and contrast a vacation day at the beach vs. a vacation day at a pool. After a brief group discussion, they were given a chart consisting of two columns; Column A was labeled 'beach' and column B was labeled 'pool'. The students were asked to fill out the chart, comparing these two experiences.

After completing this first chart, they proceeded to the second scaffolding step in which they were given a second chart with three columns: columns A and B remained the same, but a third column, (column C) had been added in which they were asked to formulate abstract criteria to describe each element that they themselves had already compared and contrasted in columns A and B. This second step involved metacognition, or thinking about thinking (Tarricone, 2011), as the students were asked to think about how to describe their findings in columns A and B in abstract terms.

An 'abstract criterion' was defined as a formulation of the general ideas behind the elements that they themselves had compared. An example given by the instructor was that if the pool is five minutes from one's house while the beach is an hour from one's house, then the abstract criterion being used in the comparison would be 'distance', or 'travel time'. Because the easy and pleasant nature of this step involved thinking and abstracting about vacation, the atmosphere in the classroom was friendly and the answers were not categorized as 'right' or 'wrong'. The goal of establishing this classroom atmosphere was to provide a safe environment for the text comparison which later followed (Tishman, Perkins and Jay 1995, 44 ), encouraging the students to listen to one another and respond respectfully to the ideas expressed by others (Ritchart, Church, \& Morrison, 2011, 37).

Only after completing these two initial scaffolding steps (pool/beach exercise) was the third scaffolding step introduced. In this third step, students were asked to complete a new chart comparing and contrasting two Biblical texts (first text comparison) using the already familiar format of columns A, B and C. After analyzing these two Biblical texts (in columns $\mathrm{A}$ and $\mathrm{B}$ ), they were once again, asked to fill in column $\mathrm{C}$, requiring them to think about their thinking and formulate abstract criteria to describe the elements they themselves had compared and contrasted in columns A and B. The fourth scaffolding step occurred a week later when their findings were discussed in class.

The fifth step in this study occurred five months later in the year, when two new Biblical texts were introduced (second text comparison). While this step followed the same format as 
the first text comparison (columns A, B, and C), there was one crucial change. This change was that the preliminary pool/beach exercise was skipped. It was briefly mentioned by the instructor just as a reminder and the students then proceeded directly to the Biblical text comparison. As a sixth scaffolding step, this second Biblical text comparison was also discussed in class the following week.

\subsection{Follow up}

The seventh and final step in the scaffolding intervention occurred a few weeks after the second text comparison, when a short questionnaire was handed out, asking the student to rate on a five point scale the contribution the 'pool/beach' exercise had in facilitating making text comparisons at later stages. The choices ranged from 'extremely helpful' to 'a waste of time'.

\section{Analysis}

\subsection{Thinking skill 1: The ability to analyze}

The first thinking skill that was examined involved analysis, defined as the ability to compare and contrast two elements generated by the student. The comparison of the two elements was assigned a score of $0 / 1$ according to the internal logic of the comparison. For example if the student compared beach and pool by noting that there is sand at the beach and concrete at the pool, this comparison was considered logical and received a score of 1 . However, if the student compared sand at the beach to the cost of the bus to get to the pool, this comparison was considered illogical and received a score of 0 . The same analysis was performed on the two biblical texts. This coding resulted in an average for the group score indicating the number of successful comparisons made for each exercise.

\subsection{Thinking skill 2: The ability to evaluate}

The second thinking skill addressed involved evaluation of what the students had compared and contrasted in their analysis. This skill is defined here as the ability to formulate an abstract criterion that accurately describes the two elements they had examined. Within the framework of Blooms' revised taxonomy, they were engaging in the fourth and fifth categories of knowledge: analyzing textual material and then evaluating their findings (Krathwohl 2002). A coding rubric of 0-3 was used to indicate the level of their abstractions when looking at the comparisons they had made.

0. unable to generate abstract criteria for their comparison

1. generates an abstract criterion for one element

2. uses the wording of the elements as an abstract criterion

3. generates an abstract criterion applying to both elements of their comparison

This coding yielded an average for the group, indicating the level of their ability to evaluate their own comparisons.

\subsection{Follow up questionnaire}

The final and seventh scaffolding step involved a questionnaire designed to assess the 


\section{Macrothink}

students' attitudes about the process, as discussed above. An average of the students' assessment of the contribution of the scaffolding exercise was obtained.

\section{Interrater Reliability}

Interrater reliability was checked by having the two researchers independently code the data. The primary researcher coded $100 \%$ of the data and her colleague coded $46 \%$ of the data. Interrater reliability measures were obtained for each of the two thinking skills. For thinking skill 1 (analysis) Cohen's kappa was used. The following scores were obtained for each of the three exercises $(1: .527, p<.0005$ showing moderate agreement; $2: .704, p<.0005$ showing substantial agreement, and 3: .358, $p<.0005$ showing fair agreement). For thinking skill 2 (evaluation), Spearman's correlation coefficient was used, and the following scores were obtained for each of the three exercises $\left(1: \mathrm{r}_{\mathrm{s}}(37)=.692, p<.001\right.$ showing strong agreement; $2: \mathrm{r}_{\mathrm{s}}(24)=.852, p<.001$ showing very strong agreement; and $3: .358, p<.0005$ showing moderate agreement.

\section{Findings}

\subsection{Thinking Skills: Analysis and evaluation}

Each of the three exercises included two parts: analysis and evaluation. In the analysis, students were asked to independently compare two situations or texts using logical parameters. In the evaluation section, students were asked to formulate an abstract criterion to describe each comparison. The results are presented below in Table 1.

Table 1. Scores for analysis and evaluation performance for three CT exercises $(\mathrm{N}=24)$

\begin{tabular}{|l|l|l|}
\hline Exercise & $\begin{array}{l}\text { Analysis: } \\
\text { Average number of parameters generated }\end{array}$ & $\begin{array}{l}\text { Evaluation: } \\
\text { Average number of correct evaluations }\end{array}$ \\
\hline Pool/beach & 3.8 & 10.6 \\
\hline First text comparison & 3.8 & 8.5 \\
\hline Second text comparison & 4.5 & 11.7 \\
\hline
\end{tabular}

As seen from the above results, there was an improvement in the students' ability to analyze by comparing situations/texts over the course of the three exercises. While in the pool/beach and first text comparison, an average of 3.8 parameters was obtained, in the second text comparison, the average increased to 4.5 .

Likewise, an improvement was found in the students' ability to evaluate their comparisons. While the score on the first text comparison was lower than the initial pool/beach score, the evaluation performance on the second text comparison was higher than both of the previous two exercises. The drop in score in the first text comparison will be addressed in the discussion section. 
7.2 Thinking Disposition: developing self confidence in one's own ability to reason

During each part of the study, the students successfully completed the assigned tasks. They completed the initial pool beach exercise within approximately 5-10 minutes. After completing this initial exercise, there were no complaints/requests for the teacher to provide them with criteria for comparison, and they worked seriously on the first text comparison for about twenty minutes. When the second text comparison was introduced months later, they again worked on completing the chart for about twenty minutes without complaining or requesting teacher support. The classroom discussions upon completion of both text comparison charts were fruitful, and many students participated in an active manner, sharing their comparisons and the abstract criteria they had chosen.

\subsection{Student feedback of the exercise}

The students' subjective assessment of the scaffolding intervention included three parts. In the first part, the students were asked to respond to the question: 'To what extent did the exercise comparing the pool to the beach help you in choosing criteria by which to compare the Biblical stories?' The students responded using a scale of 4 - 0 , ranging from extremely helpful (4) to 'not helpful at all' (0). The average score was 3.1.

In the second part of the student's evaluation, they were asked to describe the exercise by choosing one of five descriptors: effective, helpful, a waste of time, childish, and unnecessary. The descriptors chosen by the students were either effective or helpful; none chose the negative options. One student added the following comment to her evaluation: 'The exercise was very simple and extremely helpful in focusing me on the task at hand.'

\section{Discussion}

\subsection{Scaffolding}

This study utilized scaffolding as a way to promote CT amongst pre-service education students. In order to help the students compare texts independently without being told what to look for, the teacher developed a scaffolding tool based on the students' own life experience. The skills learned in the exercise were then transferred to the Biblical text comparisons.

Aspects of this study correspond to the common characteristics of scaffolding discussed above. Contingency was addressed by designing a tool to help students perform a task which they initially had claimed they could not accomplish on their own. Fading involved the gradual withdrawal of teacher support, leading to the third characteristic - the transfer of responsibility for the performance of the task from the teacher to the student, leading eventually to the student taking more control over his learning (Pol, Volman and Beishulizen 2010).

Evidence that the scaffolding procedure resulted in the students independently performing the CT tasks was found in both objective and subjective findings. The objective findings were the improved scores in the analysis and evaluation tasks. The subjective findings were the students' positive feedback on the follow up survey, expressing their feeling that the scaffolding strategy had significantly helped improve their CT skills. 
The findings regarding analysis and evaluation did not follow a steady line of improvement, and these fluctuations warrant explanation. In the analysis stage, the same average score was obtained both for the initial pool/beach exercise as for the first text comparison, while improvement occurred only for the second text comparison. In the evaluation stage, there was actually a drop from pool/beach to the first text comparison, while a marked improvement occurred only in the second text comparison.

These findings can be explained by the scaffolding intervention on completion of the first text comparison. When the teacher returned these exercises, their answers were discussed in class, providing a further learning opportunity. This class discussion may have contributed to their improved performance in the second text comparison for both analysis and evaluation.

The drop in score on evaluation between pool/beach and the first text comparison can be attributed to the difficulty they experienced in transferring the skill they had just learned in one area to another area. After successfully evaluating a situation from everyday life, the transfer of that skill to a new and less familiar area of text study was not automatic and needed further explanation (Dewitz \& Graves, 2014). This difficulty was addressed in the class discussion after the first text comparison, resulting in an improvement later on in the second text comparison.

These findings provide further evidence for the utility of scaffolding in the developing of CT skills in higher education (Ryan \& Ryan, 2013). Scaffolding was found to be an important tool for teaching CT to pre-service teachers (Yeh, 2009) and instructional design students (Sharma \& Hannafin, 2004). It is seen as an integral component of teaching students to write wikibooks (Kim, 2015), and is an important tool for teaching college students to learn independently throughout their college years so that they can learn to write their own papers and avoid plagiarism (Luke, 2014).

\subsection{An ironic difference between teacher vs. student reactions to the exercise}

When this exercise was presented to the small group of teacher educators participating in the in-service training course in developing thinking skills, almost all the teachers spontaneously reacted negatively to the exercise, dismissing it as childish. This negative reaction was in sharp contrast to the success of the exercise in the classroom and reflected by the student's positive evaluation of its efficacy which was reported above.

On this particular issue, a strong divide thus existed between what the teacher educators and the students themselves felt to be an appropriate cognitive/age level assignment. While the teacher educators considered it childish, the students themselves found it to be helpful. While it is a basic educational assumption that teachers with high expectations of their students abilities to succeed are found to be more effective as teachers (Rubie-Davies, 2007; Rubie-Davies et al., 2015), in this particular case, ironically, the opposite was true.

Teachers in the study group who had high expectations of the level of the students, discouraged the use of the 'pool/beach' exercise and were extremely skeptical in their reaction to the suggested exercise. They assumed that the students already had the ability to perform the assigned text comparison or, alternatively, assumed that even those students who 
might need help with the task would feel that the exercise was somewhat infantilizing. Ironically, having low expectations regarding the level of the students empowered this researcher to use it in class and thereby successfully advance their thinking skills.

\subsection{Considerations for improving the scaffolding}

Because the study was conducted as part of a group process, it was difficult to adapt the scaffolding to students on an individual basis. The scaffolding was developed for the group as a whole, resulting in the remediation that may not have been appropriate for each individual student's level of learning (Macrine \& Sabbatino, 2008). In order to compensate, the teacher circulated in the classroom, offering to help individuals while they completed the tasks.

An interesting and somewhat counter -intuitive finding was noticed when the pool/beach exercise was scored. As was explained above, beginning the study by thinking about a daily leisure activity was supposed to help them learn to abstract. A number of students, however, described their own subjective experience instead of formulating abstract criteria. For example, one student wrote that the pool had no waves, while the beach had waves; she then chose 'pleasure' as her abstract criteria. Instead of writing "type of water" or "ease of swimming" as abstract criteria to describe what she had compared, her choice of 'pleasure' expressed her own personal preference and did not achieve the goal of abstracting in objective terms.

An additional scaffolding step could have been added at this point in order to help them correct this problem. Devoting class time to discussing and analyzing their pool/beach choices may have helped them recognize that they had chosen a subjective description of what they had compared rather than an abstract category and helped them take a step toward thinking more abstractly, especially since the comparison involved a pleasant daily life experience and not a text. When asked to compare two texts, though, this phenomenon disappeared, as the subjective element was no longer relevant given that they were comparing texts and not life experiences.

\subsection{Limitations of the study}

This study might have yielded more reliable results through a reversal design whereby students would first be asked to compare two texts, followed by a scaffolding exercise from their own life experience (pool/beach exercise), followed by a repetition of the initial text comparison. This method was ruled out because of time constraints and a concern for 'frustration control' - also referred to as 'contingency management', an important scaffolding intention which involves keeping students motivated by preventing or minimizing frustration (Wood, Bruner, \& Ross1976 in Pol, Volman, \& Beishulizen, 2010). My concern was that repeating the text comparison would have reduced student motivation and increased their frustration; hence it was not included in the study.

\section{Conclusion}

This study explored a way to develop both critical thinking skills as well as a critical thinking disposition in freshmen teachers college students. While the students CT skills of analysis 
and evaluation improved over the course of the intervention, the strongest success of this study was in the thinking disposition developed over the course of the study, as they gained self confidence in their own ability to reason. They worked on their CT skills without teacher direction, thus developing their ability to learn autonomously. Given that before this study was undertaken, the students had complained that they were not able to compare and contrast texts by themselves, this study shows that the preliminary scaffolding exercise gave them a boost of confidence as they saw that the task could be accomplished and they could achieve biblical text comparisons and abstractions on their own.

Using a scaffolding technique was thus found to be an effective method of encouraging students CT disposition. While Faragher and Huijser (2014) found that working on students thinking skills could prevent a loss of confidence in their academic abilities, this study showed that working on students thinking skills by using a scaffolding technique could actually boost their confidence in their academic abilities, by enabling them to analyze and evaluate texts on their own when in the past they had expressed feelings of frustration and incompetence in their abilities to accomplish these thinking skills. Rooting the ability to abstract in a concrete familiar situation helped them develop the confidence to attempt abstract thinking in the context of textual analysis. While additional work could contribute to a more advanced level of analysis and evaluation, this scaffolding intervention initiated a learning process that is likely to continue throughout their college education.

\section{Acknowledgment}

I would like to thank Dr. David Brody and Dr. Linor Hadar for their help in developing this study.

\section{References}

Abrami, P. C., Bernard, R. M, Borokhovski, E., Waddington, C, Wade, A., \& Persson, T. (2015). Strategies for Teaching Students to Think Critically: A Meta-Analysis. Review of Educational Research, 85(2), 275-314. https://doi.org/10.3102/0034654314551063

Ariel, Y. (2012). Limud Gemara lebanim ubanot yachad begil hayesodi [Teaching Talmud in co-ed elementary schools]. Retrieved from http://www.yeshiva.org.il/ask/75309

Aviner, S. (1994). Limud Torah Lebanot [Teaching Torah to Girls]. Iturei Kohanim, 110. Retrieved from http://www.daat.ac.il/daat/mishpach/limud-2.htm

Bakker, A., Smit, J., \& Wegerif, R. (2015). Scaffolding and dialogic teaching in mathematics education: introduction and review. ZDM Mathematics Education, 47, 1047. https://doi.org/10.1007/s11858-015-0738-8

Basham, G., Irwin, W., Nardone, H., \& Wallace, J. M. (2011). Critical thinking: A Students Introduction (4th Ed.). McGraw Hill Education.

Bazak, A. (2013). Ad Hayom hazeh [Until this day: Fundamental Questions in Bible Teaching]. Tel Aviv: Miskal - Yedioth Ahronoth Books and Chemed Books.

Behar-Horenstein, L., \& Niu, L. (2011). Teaching critical thinking skills in higher education: 
A review of the literature. Journal of College Teaching and Learning, 8(2), 25-41. https://doi.org/10.19030/tlc.v8i2.3554

Benson, P. (2013). Teaching and Researching: Autonomy in Language Learning. N.Y.: Routlege.

Chan, V. (2001). Readiness for Learner Autonomy: what do our learners tell us? Teaching in Higher Education, 6, 4. https://doi.org/10.1080/13562510120078045

Cohen, L., Manion, L., \& Morrison, K. (2005). Research Methods in Education (5 ${ }^{\text {th }}$ Ed., pp. 226-241).

Corona, E, \& Gonzales-Quiceno, J. (2008). Curriculum for the Whole Child. Language Magazine, 7(10), 20-23.

Dewitz, P., \& Graves, M. (2014). Teaching for Transfer in the Common Core Era. Reading Teacher, 68(2), 149-158. https://doi.org/10.1002/trtr.1290

Elder, L., \& Paul, R. (2004). Critical thinking... and the art of close reading (Part II). Journal of Developmental Education, 27(3), 36.

Elder, L., \& Paul, R. (2008). Critical Thinking: The Nuts and Bolts of Education. Optometric Education, 33(3), 88-91.

Faragher, L., \& Huijser, H. (2014). Exploring evidence of higher order thinking skills in the writing of first year undergraduates. International Journal of the First Year in Higher Education, 5(2), 33-44. http://dx.doi.org/10.5204/intjfyhe.v5i2

Fitzgerald, J., \& Graves, M. F. (2004). Reading Supports for All. Educational Leadership, 62(4), 68-71.

Florence, D. C. (2014). A History of Critical Thinking as an Educational Goal in Graduate Theological Schools. Christian Higher Education, 13(5), 352-361.

Giuliano, B., \& Sullivan, J. (2007). Academic Wholism: Bridging the Gap between High School and College. American Secondary Education, 35(3), 7-18.

Graves, M. F., \& Avery, P. G. (1997). Scaffolding students' reading of history. Social Studies, 88(3). https://doi.org/10.1080/00377999709603760

Hadar, L. L., \& Brody, D. L. (2010). From isolation to symphonic harmony: Building a professional development community among teacher educators. Teaching \& Teacher Education, 26(8), 1641-1651. https://doi.org/10.1016/j.tate.2010.06.015

Hadar, L. L., \& Brody, D. L. (2012). The Interaction Between Group Processes and Personal Professional Trajectories in a Professional Development Community for Teacher Educators, Journal of Teacher Education, 64(2), 145-161. https://doi.org/10.1177/0022487112466898

Hine, G. S. (2013). The importance of action research in teacher education programs. Issues in Educational Research, 23(2), 151-163. 
Ho, J., \& Crokall, D. (1995). Breaking with Chinese cultural traditions: Learner autonomy in English language teaching. System, 23(2), 235-243. https://doi.org/10.1016/0346-251X(95) 00011-8

Hugerat, M., \& Kortam, N. (2014). Improving Higher Order Thinking Skills among freshmen by Teaching Science through Inquiry. Eurasia Journal of Mathematics, Science \& Technology Education, 10(5), 447-454. https://doi.org/10.12973/eurasia.2014.1107a

Jácome, É. (2012). Promoting Learner Autonomy through Teacher-Student Partnership Assessment in an American High School: A Cycle of Action Research. Profile: Issues In Teachers' Professional Development, 14(2), 145-162. Education Source, EBSCOhost.

Jawoniyi, O. (2015). Religious Education, Critical Thinking, Rational Autonomy, and the Child's Right to an Open Future. Religion \& Education, 42(1), 34-53. https://doi.org/10.1080/15507394.2013.859960

Kathy, L. B. (2003). From teacher-centered to learner-centered curriculum: Improving learning in diverse classrooms. Education, 124(1), 49-54. Retrieved from http://search.proquest.com/docview/196439697?accountid=14765

Kemmis, S., \& McTaggart, R. (2005). Participatory Action Research: Communicative Action and the Public Sphere. Sage Publications Ltd.

Kim, N. k. (2015). Critical thinking in wikibook creation with enhanced and minimal scaffolds. Educational Technology Research \& Development, 63(1), 5-33. https://doi.org/10.1007/s11423-014-9361-6

Krathwohl, D. (2002) A Revision of Bloom's Taxonomy: An Overview, Theory Into Practice, 41(4), 212-218. https://doi.org/10.1207/s15430421tip4104_2

Lehmann, D. (2008). Calling Integration into Question: a Discourse Analysis of English and Humash classes at a Modern Orthodox Jewish High School. Journal of Jewish Education, 74(3). https://doi.org/10.1080/15244110802418336

Littlewood, W. (1996). “Autonomy”: An anatomy and a framework. System, 24(4), 427-435. https://doi.org/10.1016/S0346-251X(96)00039-5

Lo, Y-F. (2010). Implementing reflective portfolios for promoting autonomous learning among EFL college students in Taiwan. Language Teaching Research, 14(1), 77-95. https://doi.org/10.1177/1362168809346509

Luke, B. (2014). Misconduct versus Misunderstood? Scaffolding Education and Learning. Accounting Education, 23(4), 383-385. https://doi.org/10.1177/1362168809346509

Macrine, S. L., \& Sabbatino, E. (2008). Dynamic Assessment and Remediation Approach: Using the DARA Approach to Assist Struggling Readers. Reading \& Writing Quarterly, 24(1), 52-76. https://doi.org/10.1080/10573560701753112

Many, J., \& Aoulou, E. (2014). Understanding Literacy Teacher Educators' Use of Scaffolding. Reading Horizons, 53(3), 1-34. 
Maskey, C. (2008). The coordination of clinical and didactic learning experiences to improve critical-thinking skills and academic performance. Teaching \& Learning In Nursing, 3(1), 11-15. https://doi.org/10.1177/1362168809346509

Ministry of Education, State of Israel. (1987). Religious Public School Oral Law Curriculum for Grades 1-12. Retrieved from http://www.daat.ac.il/daat/toshba/tochniut/toshba.htm

Ministry of Education, State of Israel. (2013). Pedagogical Secretariat Language Dept. English Inspectorate Revised English Curriculum Principles and Standards for Learning English as an International Language for All Grades. Retrieved from http://meyda.education.gov.il/files/HaarachatOvdeyHoraa/Englishcurriculum.pdf.

Murray, D., \& McPherson, P. (2006). Scaffolding instruction for reading the Web.Language Teaching Research, 10(2), 131-156. https://doi.org/10.1191/13621688061r189oa

Nickerson, R. S., Perkins, D. N., \& Smith, E. E. (2014). The Teaching of Thinking. Routledge.

Norris, S, P. (1985). Synthesis of research on critical thinking. Educational Leadership, 4045.

Ocak, G., \& Eğmir, E. (2016). The Relationship Between Pre-Service Teachers' Critical Thinking Tendencies and Problem Solving Skills. Participatory Educational Research, 33-44.

Ocak, Gürbüz1, gocak@aku.edu.tr, and Eray1 EĞMiR. 2016. 'The Relationship Between Pre-Service Teachers' Critical Thinking Tendencies and Problem Solving Skills.'. Education Source, EBSCOhost (accessed July 1, 2016).

O'Connor, E., McDonald, F., \& Ruggiero, M. (2014). Scaffolding Complex Learning: Integrating 21st Century Thinking, Emerging Technologies, and Dynamic Design and Assessment to Expand Learning and Communication Opportunities. Journal of Educational Technology Systems, 43(2), 199-226. https://doi.org/10.2190/ET.43.2.g

Paul, R., \& Elder, L. (2009). Critical thinking: Ethical reasoning and fair-minded thinking, Part I, Journal of Developmental Education, 1, 36-37.

Paul, R., \& Elder, L. (2012). Critical Thinking: Competency Standards Essential to the Cultivation of Intellectual Skills, Part 5. Journal of Developmental Education, 36(1), 30-31.

Perkins, D. (2001). The Social Side of Thinking. In A. Costa (Ed.), Developing Minds: A Resource Bookfor Teaching Thinking. Alexandria, Virginia, ASCD, pp. 158-163.

Pierson, H. D. (1996). Learner culture and learner autonomy in the Hong Kong Chinese context. Taking control: Autonomy in language learning, 49-58.

Pol, J. D., Volman, M., \& Beishuizen, J. (2010). Scaffolding in Teacher-Student Interaction: A Decade of Research. Educational Psychology Review, 22(3), 271-296. https://doi.org/10.1007/s10648-010-9127-6

Puntambekar, S., \& Hübscher, M. R. (2005). Tools for Scaffolding Students in a Complex 


\section{Macrothink}

Journal of Education and Training

ISSN 2330-9709

2017, Vol. 4, No. 1

Learning Environment: What Have We Gained and What Have We Missed? Educational Psychologist, 40(1), 1-12. https://doi.org/10.1207/s15326985ep4001_1

Raviv, D. (2011). Pituach Hashivah belimud miktzo'ot hahayadut [Developing thinking in the teaching of Jewish Studies]. Oreshet, 2, 279-293.

Raviv, D., \& Kaniel, S. (2013). Hashiva veTalmud [Thinking and Talmud]. Jerusalem: Reuven Mas.

Ritchart, R., \& Perkins, D. (2008). Making Thinking Visible. Educational Leadership, 65(5), 57-61.

Ritchart, R., Church, M., \& Morrison, K. (2011). Making Thinking Visible. San Fransisco, Jossey-Bass.

Rodrigues, K. J. (2012). It Does Matter How We Teach Math. MPAEA Journal of Adult Education, 41(1), 29-33.

Rubie-Davies, C. M. (2007). Classroom interactions: Exploring the practices of high- and low-expectation teachers. British Journal of Educational Psychology, 77(2), 289-306. https://doi.org/10.1348/000709906X101601

Rubie-Davies, C., Peterson, E., Sibley, C., \& Rosenthal, R. (2015). A teacher expectation intervention: Modelling the practices of high expectation teachers. Contemporary Educational Psychology, 4072-85. https://doi.org/10.1016/j.cedpsych.2014.03.003

Ryan, M., \& Ryan, M. (2013). Theorising a model for teaching and assessing reflective learning in higher education. Higher Education Research \& Development, 32(2), 244-257. https://doi.org/10.1080/07294360.2012.661704

Saiz, C., \& Rivas, S. (2011). Evaluation of the ARDESOS program: An initiative to improve critical thinking skills. Journal of the Scholarship of Teaching \& Learning, 11(2), 34-51.

Samanci, N. K. (2015). A Study on the Link between Moral Judgment Competences and Critical Thinking Skills. International Journal of Environmental \& Science Education, 10(2), 135-143. https://doi.org/10.12973/ijese.2015.236a

Sendag, S., Erol, O., Sezgin, S., \& Dulkadir, N. (2015). Preservice Teachers' Critical Thinking Dispositions and Web 2.0 Competencies. Contemporary Educational Technology, 6(3).

Sharma, P., \& Hannafin, M. (2004). Scaffolding Critical Thinking in an Online Course: An Exploratory Study. Journal of Educational Computing Research, 31(2), 181-208. https://doi.org/10.2190/TMC3-RXPE-75MY-31YG

Silva, M., Lopes, J., \& Silva, A. (2013). Using Senses and Sensors in the environment to develop abstract thinking - a theoretical and instrumental framework. Problems of Education In The 21St Century, 53, 99-119.

Tarricone, P. (2011). The taxonomy of metacognition. Psychology Press.

Tau, Z. (2002). A Righteous Man lives by his beliefs [Zaddik beEmunato Yihyeh] Jerusalem. 


\section{Macrothink}

Tillapaugh, D., \& Haber-Curran, P. (2013). At the intersection of leadership and learning: a self-study of using student-centered pedagogies in the classroom. Educational Action Research, 21(4). https://doi.org/10.1080/09650792.2013.832345

Tishman, S. (2001). Added value: A dispositional perspective on thinking. Developing minds: A resource book for teaching thinking, 72-75.

Tishman, S., Perkins, D., \& Jay, E. (1995). The Thinking Classroom. Boston: Allyn and Bacon. Torff, B. (2005). Developmental changes in Teachers' Beliefs About Critical-Thinking $\begin{array}{llll}\text { Activities. Journal of Educational Psychology, } & \text { 97, }\end{array}$ https://doi.org/10.1037/0022-0663.97.1.13

Valanides, N., \& Angeli, C. (2005). Scaffolding Complex learning with a computer modeling tool in a science education methods course. Proceedings of The IADIS International Conference On Cognition \& Exploratory Learning In Digital Age, 485-488.

Wegerif, R., Li, L., \& Kaufman, J. C. (Eds.). (2015). The Routledge International Handbook of Research on Teaching Thinking. Routledge.

Wood, D., Bruner, J. S., \& Ross, G. (1976). The role of tutoring in problem solving. Journal of Child Psychology \& Psychiatry \& Allied Disciplines, 17(2), 89-100. https://doi.org/10.1111/j.1469-7610.1976.tb00381.x

Yeh, Y. (2009). Integrating e-learning into the Direct-instruction Model to enhance the effectiveness of critical-thinking instruction. Instructional Science, 37(2), 185-203. https://doi.org/10.1007/s11251-007-9048-z

\section{Copyright Disclaimer}

Copyright reserved by the author(s).

This article is an open-access article distributed under the terms and conditions of the Creative Commons Attribution license (http://creativecommons.org/licenses/by/3.0/). 